\title{
Isolasi ekstrak kulit batang J.multifida L., serta implementasinya pada modul pembelajaran Kimia Organik Bahan Alam
}

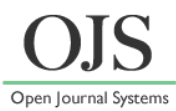

\author{
Reni Jumika $^{1^{*}}$, Agus Sundaryono ${ }^{1}$, Nurhamidah ${ }^{2}$ \\ ${ }^{1}$ Pascasarjana Pendidikan IPA FKIP Universitas Bengkulu, Bengkulu \\ ${ }^{2}$ Pendidikan Kimia FKIP Universitas Bengkulu, Bengkulu \\ *Email: renibundaaqnish@gmail.com
}

\begin{abstract}
ABSTRAK
Penelitian ini bertujuan untuk mengetahui bagaimana hasil karakterisasi senyawa metabolit sekunder dari hasil isolasi kulit batang J. multifida $L$ dan bagaimana peningkatan hasil belajar mahasiswa pada pembelajaran kimia organik bahan alam menggunakan modul. Kulit batang J. multifida $L$ dimaserasi menggunakan etanol (96\%), filtrat diuapkan menggunakan rotary evaporator, kemudian difraksinasi cair-cair menggunakan pelarut dengan kepolaran bertingkat berturut-turut dengan pelarut nheksana dan etil asetat. Tahap selanjutnya, Isolasi sampel menggunakan kromatografi kolom. Implementasi penggunaan modul dilakukan pada mahasiswa Pendidikan kimia semester VI pada mata kuliah kimia organik bahan alam (KOBA). Mata kuliah ini hanya diikuti oleh satu kelas yang bertindak sebagai kelas eksperiment. Pada awal pembelajaran dilakukan pretest dan diakhir pembelajaran diberikan posttest. Senyawa metabolit sekunder yang dapat diisolasi dari fraksi n-heksan pada kulit batang J.multifida L., Berdasarkan hasil analisis spektroskopi diduga bahwa senyawa memiliki kerangka senyawa steroid dengan golongan Stigmasterol dengan rumus molekul $\mathrm{C}_{29} \mathrm{H}_{48} \mathrm{O}$. Pembelajaran Kimia Organik Bahan Alam (KOBA) dengan menggunakan modul memberikan peningkatan hasil belajar mahasiswa, terdapat perbedaan secara signifikan antara nilai rata-rata posttest $(82,4)$ dengan rata-rata nilai pretest $(58,4)$ dan $\mathrm{KKM}(75)$.
\end{abstract}

Kata kunci: Kulit batang J.multifida L; isolasi; hasil belajar; modul.

\section{PENDAHULUAN}

Indonesia merupakan salah satu pusat keanekaragaman hayati terkaya di dunia. Tingginya kekayaan keanekaragaman tumbuhan ditunjukkan oleh pencapaian sebagai urutan negara terbesar ketujuh yang memiliki $25 \%$ dari spesies tumbuhan berbunga dan 40\%nya merupakan tumbuhan endemik Indonesia (Muchtaroma, 2011). Sejak ratusan tahun yang lalu, nenek moyang bangsa kita telah terkenal pandai meracik jamu dan obat-obatan tradisional. Beragam jenis tumbuhan, akar-akaran, dan bahan-bahan alamiah lainnya diracik sebagai ramuan jamu untuk menyembuhkan berbagai penyakit.

Saat ini dunia kedokteran modern pun telah banyak kembali mempelajari obat-obat tradisional. Tumbuhan berkhasiat obat ditelaah dan dipelajari secara ilmiah. Hasil penelitian mendukung bahwa tumbuhan obat memang memiliki kandungan zat-zat atau senyawa yang secara klinis terbukti bermanfaat bagi kesehatan (Muhlisah, 2005). Tumbuhan ini dapat digunakan sebagai obat-obatan tradisional, karena di dalam tumbuhan tersebut terkandung senyawa metabolit sekunder yang memiliki keaktifan biologis seperti flavonoid, terpenoid, triterpenoid, kumarin, kromon, kuinon, resin dan sebagainya. Secara umum, kegunaan tumbuhan obat sebenarnya disebabkan oleh kandungan kimia yang dimilikinya. Senyawa kimia aktif yang berasal dari tumbuhan sangat penting dalam bidang pengobatan, maka perlu dilakukan penelitian yang sistematis untuk mendapatkan senyawa-senyawa dari tumbuhan yang belum pernah diteliti sebelumnya. Metabolit sekunder dalam tumbuhan biasanya tersebar merata ke seluruh bagian tumbuhan tetapi dalam kadar yang berbeda-beda. Salah satu pada tanaman 
jarak tintir, oleh masyarakat Bengkulu lebih dikenal dengan tanaman betadin Jatropha multifida linn.

Tanaman Jatropha multifida linn (Euphorbiaceae) merupakan tanaman yang memiliki banyak sekali khasiat sebagai obat tradisional, Penduduk Nigeria memanfaatkan tanaman ini sebagai obat tradisional untuk mengobati berbagai jenis infeksi. J. multifida L., mengandung senyawa alkaloid jatrophine yang bisa digunakan untuk proses pembekuan darah, atau digunakan sebagai obat luka baru (Anonim, 2008).

Salah satu cabang ilmu kimia yang concern terhadap pemanfaatan tumbuhan obat ialah Kimia Organik Bahan Alam. Mata Kuliah Kimia Organik Bahan Alam (KOBA) merupakan mata kuliah pilihan untuk mahasiswa program studi S1 Pendidikan Kimia Fakultas Keguruan dan Ilmu Pendidikan Universitas Bengkulu dengan bobot 2 SKS Teori. Pembelajaran kimia organik bahan alam (KOBA) adalah suatu pembelajaran yang merupakan salah satu cabang dari ilmu kimia yang membahas senyawasenyawa kimia yang terdapat dalam bahan alam baik dari tumbuhan atau hewan. Oleh karena itu peranan sumber belajar sangat diperlukan dalam proses pembelajaran KOBA guna pencapaian pemahaman yang utuh. Sumber belajar secara fungsional dapat membantu optimalisasi hasil belajar.Salah satu sumber belajar yang efektif digunakan dalam pembelajaran KOBA yakni modul. Modul merupakan pembelajaran yang utuh yang dapat dipelajari oleh peserta didik secara mandiri, disusun secara sistematis mengacu pada tujuan pembelajaran (Sukiman, 2012).

Penelitian Lokaria (2012) menyatakan bahwa pembelajaran menggunakan modul dapat meningkatkan hasil belajar mahasiswa. Hal ini ditunjukan adanya peningkatan hasil belajar yang didukung oleh perbedaan yang signifikan antara kelas eksperimen dan kelas kontrol baik hasik kognitif, afektif maupun psikomotorik pada pembelajaran KOBA dengan menggunakan modul sebagai sumber belajar. Hasil penelitian Putra (2014) turut mendukung bahwa bentuk sumber belajar yang efektif pada pembelajaran KOBA yakni menggunakan modul. Hal tersebut dikarenakan nilai rata-rata hasil pre test mahasiswa mengalami peningkatan pada post test yang lebih besar dari standar KKM mata kuliah KOBA. Peranan dan penggunaan sumber belajar secara terencana dan terprogram akan berpengaruh pada pencapaian tujuan pembelajaran yang ditargetkan.

\section{METODE PENELITIAN}

Batang J. multifida L, segar dibersihkan dengan air mengalir, kemudian dikeringkan dalam ruangan yang tidak disinari langsung oleh matahari dan dipotong kecil-kecil, dimaserasi dengan etanol teknis $96 \%$ dalam gelas berukuran 25 liter, kemudian disimpan di tempat terlindung cahaya selama 10 hari sambil aduk. Hasil maserasi dipisahkan dengan menggunakan kertas saring. Filtrat yang diperoleh kemudian dipekatkan dengan menggunakan rotary evaporator, kemudian di uji fitokimia kembali untuk meyakinkan apakah benar adanya kandungan senyawa flavonoid, alkaloid dan terpenoid.

Ekstrak etanol kemudian difraksinasi caircair dengan corong pisah menggunakan pelarut dengan kepolaran bertingkat berturut-turut dengan pelarut $n$-heksana dan etil asetat.

Ekstrak etanol ditempatkan dalam corong pisah, ke dalamnya ditambahkan pelarut $n$ heksana dengan perbandingan 1:1, kemudian dikocok secara perlahan hingga tercampur, kemudian didiamkan hingga tepat memisah menjadi 2 fase. Fase $n$-heksana yang telah terkumpul dipekatkan menggunakan alat rotary evaporator dan penangas air. Fase ekstrak difraksinasi kembali dengan menggunakan pelarut etil asetat dengan perbandingan 1:1, proses fraksinasi ini dilakukan tiga kali hingga diperoleh fase etil asetat dan fase ekstrak. Fase etil asetat kemudian dipekatkan dengan alat rotary evaporator dan penangas air.

Untuk mengambil senyawa yang terkandung dalam kulit batang J. multifida L, maka diisolasi menggunakan kromatografi kolom dengan tujuan untuk mengetahui plat kromagtogram yang dihasilkan dari pemisahan senyawa yang terdapat pada sampel. Pemilihan eluen dimulai dengan membandingkan 2 pelarut organic sebagai eluen, yaitu etanol 96\%: nheksana, etanol 96\%: etil asetat dan n-heksana : etil asetat. Pelarut ini campurkan dengan variasi perbandingan . 
Ekstrak senyawa yang diperoleh yang telah dipisahkan dengan cara kromatografi kolom diidentifikasi dengan IR dan NMR.

Data yang diperoleh dari hasil pembelajaran KOBA kemudian dianalisa. Ada dua jenis data penelitian yang akan dianalisis yaitu data hasil validasi modul dan data hasil validasi instrument tes. Analisa data untuk uji validasi ahli menggunakan Intracorelation class coefisien (ICC).

Keterangan :

$$
I C C=\frac{R K_{b}-R K_{e}}{R K_{b}+(p-1) R K_{e}}
$$

ICC $=$ Koefisien Intracorelation class coefisien

$\mathrm{RK}_{\mathrm{e}}=$ Rata-rata Kuadrat error

$\mathrm{RK}_{\mathrm{b}}=$ Rata- rata kuadrat butir

$\mathrm{P}=$ panelis

Uji normalitas dilakukan untuk mengetahui apakah sampel yang diteliti berdistribusi normal atau tidak.

Keterangan :

$$
\mathrm{Z}=\frac{X-\mu}{S}
$$

$\mathrm{Z}=\mathrm{Uji}$ Normalitas Kolmogorov - Smirnov

$\mathrm{X}=$ Skor data variabel yang akan diuji normalitasnya

$\mu=$ Nilai rata-rata

$\mathrm{S}=$ Standar deviasi

Uji homogenitas dilakukan untuk mengetahui apakah sampel yang diteliti berdistribusi homogen atau tidak.

$$
\mathrm{F}_{\mathrm{h}}=\frac{\text { VarianTerbesar }}{\text { VarianTerkecil }}
$$

$F_{h} \geq F_{t}$, Homogen (Variannya sama)

Data interval dianalisis dengan SPSS dengan parametrik berupa uji $t$ satu sampel dengan rumus uji :

Keterangan :

$$
t_{\text {hitung }}=\frac{\bar{x}_{1}-\mu_{0}}{\frac{S}{\sqrt{n}}}
$$

$$
\begin{array}{ll}
\bar{x}_{1} & =\text { rata-rata nilai post test } \\
\mu_{0} & =\text { nilai rata-rata standar }(\mathrm{KKM}) \\
S & =\text { standar deviasi dari post test } \\
n & =\text { jumlah peserta yang ikut post } \\
& \text { test }
\end{array}
$$

\section{HASIL DAN PEMBAHASAN}

\section{Uji kemurnian Senyawa Hasil Isolasi}

Uji kemurnian senyawa hasil isolasi dilakukan melalui uji kromatografi lapisisan tipis (KLT). Hasil KLT yang diperoleh di cantumkan pada gambar 2 .
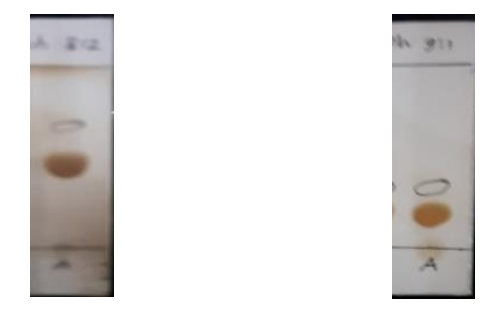

Gambar. 1. Hasil KLT (a) n-heksan:etil asetat 8:2 dan (b) n-heksan:etil asetat 9:1

(b)

Dari hasil KLT yang terlihat pada gambar 1, diperoleh noda tunggal dengan nilai $\mathrm{Rf} 0,5$ pada perbandingan $n$-heksan : etil asetat 8:2 dan 0,17 pada perbandingan n-heksan : etil asetat 9:1.

Isolasi senyawa dilakukan terhadap fraksi etil asetat karena fraksi asetat ini mempunyai aktivitas antijamur yang tidak jauh berbeda dengan fraksi n-heksan. Isolasi atau Pemisahan senyawa pada fraksi etil asetat dilakukan menggunakan kromatografi kolom. Sebanyak 1,14 gram fraksi etil asetat dilakukan isolasi dengan kolom kromatografi secara step geadient polarity $(S G P)$ atau peningkatan kepolaran pelarut, menggunakan pelarut n-heksan, etil asetat dan etanol digunakan etanol diperoleh 31 botol volume $100 \mathrm{ml}$. Proses pemisahan dilakukan dengan mengaliri pelarut $n$-heksana, $\mathrm{n}$ heksan : etil asetat : etanol ke dalam kolom untuk mengelusi sampel. Selanjutnya seluruh eluat yang dihasilkan tersebut diamati pola pemisahannya menggunakan teknik KLT dengan campuran eluen n-heksan : etil asetat.

dan etil asetat : etanol. Setelah kering diamati bahwa terdapat botol 8, 9, 10 dan dicuci dengan n-heksan lalu direkristalisasi (n-heksan-etil asetat), diperoleh Kristal warna putih sebanyak $39,4 \mathrm{mg}$. 


\section{Karakterisasi spectra IR}

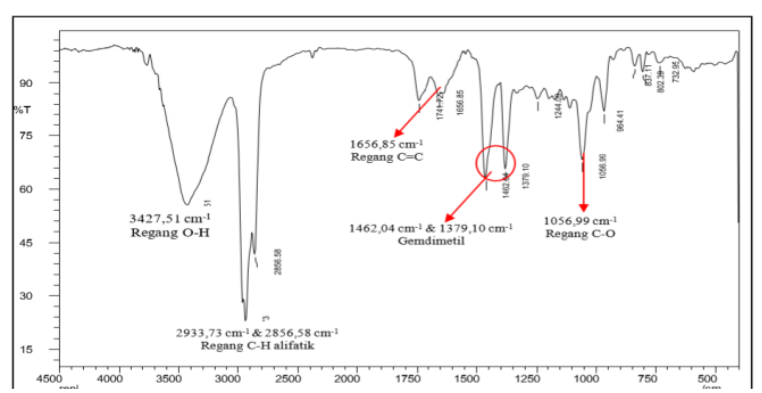

Gambar 2. Spektrum inframerah Senvawa hasil

Spektrum inframerah senyawa hasil isolasi (Gambar 2) menunjukkan adanya gugus fungsi utama yaitu gugus hidroksil $(-\mathrm{OH})$ terlihat pada bilangan gelombang $3427,71 \mathrm{~cm}^{-1}$. Hal ini diperkuat dengan adanya regang $\mathrm{C}-\mathrm{O}$ pada daerah sidik jari yaitu pada daerah $1056,99 \mathrm{~cm}^{-1}$. Selain itu terdapat regang C-H sp ${ }^{3}$ terjadi pada daerah bilangan gelombang 2800-3000 $\mathrm{cm}^{-1}$ yaitu adanya dua pita serapan pada $2933,73 \mathrm{~cm}^{-1}$ dan 2856,58 $\mathrm{cm}^{-1}$ yang diduga berasal dari regang $\mathrm{C}-\mathrm{H}$ simetris dan asimetris $\mathrm{CH}_{2}$. Keberadaan gem dimetil diperkuat oleh adanya lentur C-H pada bilangan gelombang 1462,04 $\mathrm{cm}^{-1}$ dan $1379,10 \mathrm{~cm}^{-1}$. Pita serapan pada $1656,85 \mathrm{~cm}^{-1}$ mengindikasikan adanya ikatan $\mathrm{C}=\mathrm{C} \mathrm{sp}^{2}$ yang karakteristik.

\section{HASIL PENELITIAN PEMBELAJARAN}

Tabel 1. Hasil Validasi Modul

\begin{tabular}{|c|c|c|c|c|}
\hline SV & JK & $\mathrm{Db}$ & VAr & $\mathrm{ICC}(\mathrm{r} 11)$ \\
\hline Penilai & 0.1404 & 2 & 0.0702 & \multirow{4}{*}{0.7566} \\
\hline Butir & 7.9298 & 18 & 0.4405 & \\
\hline Error & 3.8596 & 36 & 0.1072 & \\
\hline Total & 11.9298 & 56 & & \\
\hline
\end{tabular}

Kriteria : ICC $\geq 0,7$ : Dapat dipercaya;

ICC $\leq 0,7$ : Tidak dapat dipercaya

Nilai ICC yang dihasilkan adalah 0.7566 . Hasil ICC ini menunjukkan bahwa hasil tes dapat dipercaya (reliabilitas). Hal ini sesuai dengan kriteria ICC bahwa, jika nilai ICC $\leq 0,7$ ( tes tidak dapat dipercaya), ICC $\geq 0,7$ (tes dapat dipercaya). Oleh Karena ICC hasil validasi isi modul $\geq 0,7$ maka hasil tes panelis untuk validasi modul ini dapat dipercaya.
Tabel 2. Uji Reliabilitas Instrumen

\begin{tabular}{|c|c|}
\hline Instrument & Alpha \\
\hline Tes & 0,7822 \\
\hline
\end{tabular}

Koefisien reliabilitas alpha sebesar 0,7822. Kriteria dapat dikatakan termasuk dalam kategori baik dan reliabel. Untuk menentukan butir-butir instrumen tes dinyatakan reliabel dan dapat digunakan sebagai alat ukur hasil belajar jika nilai reliabilitas sama dengan atau lebih besar dari 0,7 .

\section{Data hasil belajar}

Berdasarkan hasil pretest tersebut diketahui rata-rata skor yang didapat yaitu 58,4 dengan skor terendah 33, skor tertinggi 74 dan nilai terbanyak yang diperoleh mahasiswa berkisar pada interval 63-68. Sebaran antar rentang nilai disajikan pada Gambar 7.

Tabel 3. Hasil pretest

\begin{tabular}{|c|c|c|}
\hline Interval & $\begin{array}{l}\text { Frekuensi } \\
\text { Pretest }\end{array}$ & f kom \\
\hline $33-38$ & 1 & 1 \\
\hline $39-44$ & 1 & 2 \\
\hline $45-50$ & 2 & 4 \\
\hline $51-56$ & 5 & 9 \\
\hline $57-62$ & 2 & 11 \\
\hline $63-68$ & 7 & 18 \\
\hline $69-74$ & 2 & 20 \\
\hline
\end{tabular}

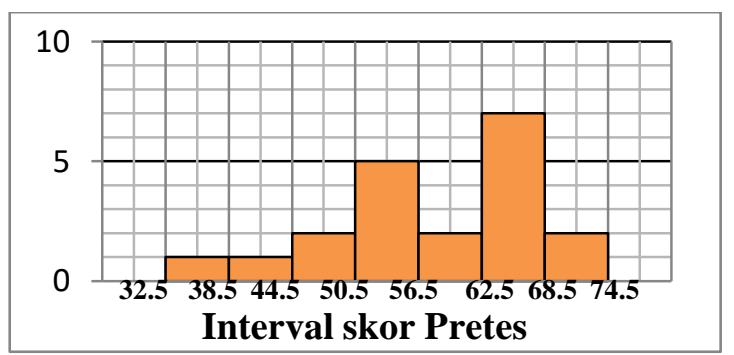

Gambar 3. Histogram hasil pretest mahasiswa 
Tabel 4. Hasil post-test

\begin{tabular}{|l|c|l|}
\hline Interval & $\begin{array}{l}\text { Frekuensi } \\
\text { posttest }\end{array}$ & f kom \\
\hline $59-64$ & 1 & 1 \\
\hline $65-70$ & 2 & 3 \\
\hline $71-76$ & 3 & 6 \\
\hline $77-82$ & 2 & 8 \\
\hline $83-88$ & 8 & 16 \\
\hline $89-94$ & 2 & 18 \\
\hline $95-100$ & 2 & 20 \\
\hline
\end{tabular}

Berdasarkan hasil posttest tersebut diketahui rata-rata skor yang didapat yaitu 82,4 dengan skor terendah 60 , skor tertinggi 100 , dan nilai terbanyak diperoleh mahasiswa berkisar pada interval 83-88. Sebaran antar rentang nilai posttest mahasiswa disajikan pada Gambar 8.

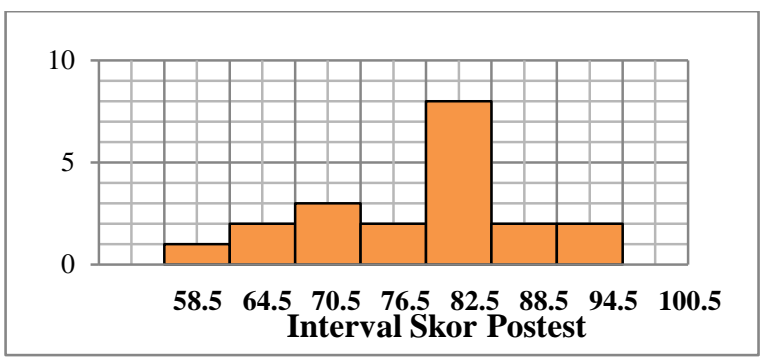

Gambar 4. Histogram hasil posttest mahasiswa

Tabel 5. Hasil Uji t satu sampel

\begin{tabular}{|c|c|c|c|c|c|c|}
\hline & \multicolumn{6}{|c|}{ Test Value $=75$} \\
\hline & \multirow[b]{2}{*}{$\mathrm{t}$} & \multirow[b]{2}{*}{ Df } & \multirow[b]{2}{*}{$\begin{array}{l}\text { Sig. }(2- \\
\text { tailed) }\end{array}$} & \multirow[b]{2}{*}{$\begin{array}{c}\text { Mean } \\
\text { Difference }\end{array}$} & \multicolumn{2}{|c|}{$\begin{array}{l}\text { 95\% Confidence } \\
\text { Interval of the } \\
\text { Difference }\end{array}$} \\
\hline & & & & & Lower & Upper \\
\hline $\begin{array}{c}\text { Postte } \\
\text { st }\end{array}$ & 3.165 & 19 & .005 & 7.400 & 2.51 & 12.29 \\
\hline
\end{tabular}

Dari hasil perhitungan uji-t satu sampel, hasil posttest pada taraf sgnifikansi 0,05 dan derajat kebebasan $(\mathrm{df})=19$ diperoleh $\mathrm{t}_{\text {hitung }}=$ 3.165 dan $t_{\text {tabel }}=2,093$. Karena $t_{\text {hitung }}>t_{\text {tabel }}$, maka hipotesis nol $\left(\mathrm{H}_{0}\right)$ ditolak. Berarti hasil pembelajaran dengan menggunakan modul lebih tinggi dari pada KKM. Kemudian dilanjutkan analisis uji $t$ sampel berpasangan. Uji ini bertujuan untuk membandingkan pengukuran sebelum (pretest) dan sesudah dilakukan sebuah perlakuan (posttest). Perlakuan yang dimaksud yaitu pembelajaran KOBA menggunakan modul sebagai sumber belajar. Hasil uji t berpasangan dicantumkan pada tabel 6 .

Tabel 6. Hasil uji t berpasangan

\begin{tabular}{|l|c|c|c|c|c|c|}
\hline & \multicolumn{3}{|c|}{ Paired Differences } & \multicolumn{3}{c|}{} \\
\hline $\begin{array}{l}\text { Postes- } \\
\text { Pretes }\end{array}$ & & & & & & \\
& Mean & $\begin{array}{c}\text { Std. } \\
\text { Deviation }\end{array}$ & $\begin{array}{c}\text { Std. Error } \\
\text { Mean }\end{array}$ & t & Df & $\begin{array}{c}\text { Sig. (2- } \\
\text { tailed) }\end{array}$ \\
\cline { 2 - 8 } & 24.000 & 14.459 & 3.233 & 7.423 & 19 & .000 \\
\hline
\end{tabular}

Dari hasil perhitungan uji $t$ sampel berpasangan pada taraf signifikansi 0,05 dan derajat kebebasan $(\mathrm{df})=19$ diperoleh $\mathrm{t}_{\text {hitung }}=$ 7.423 dan $t_{\text {tabel }}=2,093$. Karena $t_{\text {hitung }}>t_{\text {tabel }}$, maka hipotesis nol $\left(\mathrm{H}_{0}\right)$ ditolak. Artinya nilai posttest lebih baik dari nilai pretest atau pembelajaran dengan modul dapat meningkatkan hasil belajar KOBA.

\section{KESIMPULAN}

Senyawa metabolit sekunder yang dapat diisolasi dari fraksi n-heksan pada kulit batang J.multifida L., Berdasarkan hasil analisis spektroskopi diduga bahwa senyawa memiliki kerangka senyawa steroid dengan golongan Stigmasterol dan rumus molekul $\mathrm{C}_{29} \mathrm{H}_{48} \mathrm{O}$. Pembelajaran Kimia Organik Bahan Alam (KOBA) dengan menggunakan modul memberikan peningkatan hasil belajar mahasiswa, dimana terdapat perbedaan secara signifikan antara nilai rata-rata posttest $(82,4)$ dengan rata-rata nilai pretest $(58,4)$ dan KKM (75).

\section{UCAPAN TERIMA KASIH}

Penulis mengucapkan terima kasih kepada pengelola Laboratorium Mikrobiologi Fakultas Kedokteran UNIB atas bantuan dalam pelaksanaan penelitian ini. 


\section{DAFTAR PUSTAKA}

Anonim, 2008. Informasi tanaman obat, www.mahkota dewa.com: Yogyakarta

Lokaria, E. 2012. Isolasi dan Uji Aktivitas Ekstrak J.multifida L Terhadap Leukosit M.musculus Diinduksi Imunos Serta Aplikasinya Pada Pembelajaran Kimia Dengan Menggunakan Modul [thesis]. Bengkulu : Universitas Bengkulu

Muchtaroma, B. 2011. Keanekaragaman Hayati Indonesia Dalam Dunia Global .http://cloud.papua.go.id/id/keanekaragama nhayati/artikel/Pages/Artikel-Biodiversity3.aspx/

Muhlisah, F. 2005. Tanaman Obat Keluarga. Penebar Swadaya: Jakarta

Pierre, L.L. \& Moses, M.N. 2015. Isolation and Characterisation of Stigmasterol and B Sitosterol from Odontonema stictum ( Acanthaceae). JIPBS. Vol 2(1). 88-95.

Putra, D. D. 2014. Pengaruh Ekstrak, Fraksi dan Isolat Murni Umbi Simbagh Utak (Hydrohytum sp.) Sebagai Antibakteri serta implementasinya sebagai modul pembelajaran KOBA[thesis]. Bengkulu : Universitas Bengkulu

Sukiman. 2012. Pengembangan Media Pembelajaran. Yogyakarta: Pedadogia 